\section{Nauplius}

The Journal OF The

Brazilian Crustacean Society

e-ISSN 2358-2936

www.scielo.br/nau www.crustacea.org.br

\title{
The stony coral Agaricia tenuifolia Dana, 1848 as a new gall crab host (Decapoda: Cryptochiridae)
}

\author{
Godfried W.N.M. van Moorsel ${ }^{1}$ (iD orcid.org/0000-0002-5271-9178
}

Sancia E.T. van der Meij ${ }^{2,3,4}$ iD orcid.org/0000-0002-3759-8945

\author{
1 Ecosub, Doorn, The Netherlands \\ GWNMvM E-mail vanMoorsel@ecosub.nl \\ 2 Oxford University Museum of Natural History, University of Oxford, UK \\ 3 Linacre College, University of Oxford, UK \\ 4 Naturalis Biodiversity Center, Leiden, The Netherlands \\ SETvDM E-mail sancia.vandermeij@naturalis.nl \\ ZOOBANK http://zoobank.org/urn:lsid:zoobank.org:pub:A5761277-D4FE-4D55- \\ 99F3-11A4CB5ECE38
}

\begin{abstract}
Infrequently studied coral species are seldom mentioned as host organisms of associated fauna. Here we report on the stony coral Agaricia tenuifolia Dana, 1848 hosting a gall crab (Cryptochiridae). This coral-dwelling crab was observed at the southern coast of Bonaire in the Dutch Caribbean. Based on the shape of the dwelling, and the host specificity of cryptochirids, the crab is tentatively identified as Opecarcinus hypostegus (Shaw \& Hopkins, 1977).
\end{abstract}

\section{KEY WORDS}

Associated organisms, Caribbean, Crustacea, host specificity, Scleractinia.

In the Caribbean, many stony corals are host to one or more associated organisms, including numerous crustacean species (Zlatarski and MartínezEstalella, 1982). About 30 scleractinian species are known to be inhabited by one of three coral gall crabs of the family Cryptochiridae (Kropp and Manning, 1987; van der Meij, 2014; Hoeksema et al., 2017): Kroppcarcinus siderastreicola Badaro, Neves, Castro \& Johnsson, 2012, Troglocarcinus corallicola Verrill, 1908, and Opecarcinus hypostegus (Shaw \& Hopkins, 1977). The latter species is known to only inhabit corals belonging to the family Agariciidae; five Agaricia species (Agaricia agaricites (Linnaeus, 1758), Agaricia fragilis Dana, 1848, Agaricia grahamae Wells, 1973, Agaricia humilis Verrill, 1901, and Agaricia lamarcki H. Milne Edwards \& Haime, 1851) as well as Helioseris cucullata (Ellis \& Solander, 1786) host this gall crab. Earlier 
records of O. hypostegus inhabiting Siderastrea Blainville, 1830 corals are doubtful, and should likely be attributed to K. siderastreicola (Hoeksema et al., 2017).

On 18 November 2016, during a period of relatively low wave-action, a shore-dive was made in front of the lighthouse Willemstoren ( $\left.12^{\circ} 01^{\prime} 39^{\prime \prime} \mathrm{N} 68^{\circ} 14^{\prime} 12^{\prime \prime} \mathrm{W}\right)$ at the southern coast of Bonaire (Dutch Caribbean). At this locality, corals were investigated for the presence of cryptochirid crabs. Photos were taken with a Nikon D7100 with $60 \mathrm{~mm}$ lens in a Hugyfot housing. Between 5 and $15 \mathrm{~m}$ depth, around the drop-off, many colonies of Agaricia tenuifolia Dana, 1848 were present. In one of these colonies a gall crab was encountered and photographically documented (Fig. 1). The identity of the gall crab was not confirmed by a collected specimen, but the shape of the dwelling strongly indicates the presence of O. hypostegus (compare Kropp and Manning, 1987: Fig. 10d, e). Moreover, no other cryptochirids are known to inhabit Agariciidae corals (van der Meij, 2014; Hoeksema et al., 2017; van Tienderen and van der Meij, 2017). A future effort to collect gall crabs from A. tenuifolia might be undertaken to confirm the crab's identity. But even in the implausible case that the crab belongs to another cryptochirid species, this observation is relevant, as it is the first record of $A$. tenuifolia acting as a host to gall crabs. In the Agariciidae, only Agaricia undata (Ellis \& Solander, 1786) and Leptoseris cailleti (Duchassaing \& Michelotti, 1864) have not yet been found inhabited by gall crabs. As both species occur relatively deep (ca 20-80 m depth and 30-150 m depth, respectively) they are less likely to be encountered by divers (Aronson et al., 2008). In addition, L. cailleti is a rarely reported, uncommon coral species (Fenner, 2001).

Infrequently studied species such as $A$. tenuifolia are rarely mentioned in lists of host organisms (Nelson et al., 2016; Hoeksema et al., 2017). Several nonmutually exclusive explanations exist for the lack of data on symbionts of $A$. tenuifolia. Two explanations are related to research: 1 ) The species is known to occur in turbulent water, not easily accessible for underwater research, and 2) Presence of $A$. tenuifolia is not always

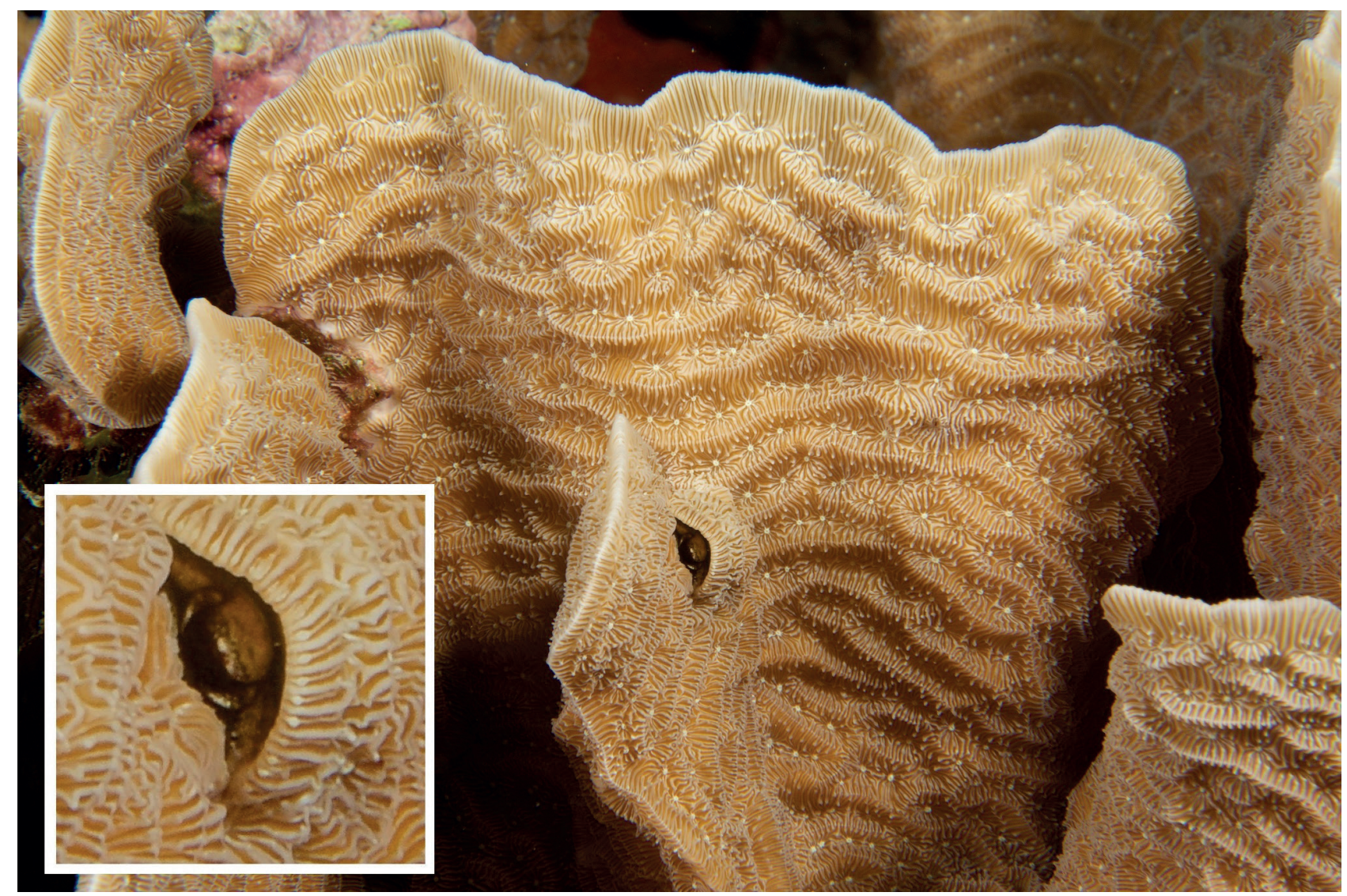

Figure 1. A gall crab, tentatively identified as Opecarcinus hypostegus, in its dwelling (inset) in the scleractinian coral Agaricia tenuifolia at Willemstoren, Bonaire. 
noticed in research due to its similarity to its congener A. agaricites. Experienced observers have expressed difficulties to discern between the species (van Duyl, 1985). Colonies of $A$. tenuifolia form large box-like structures consisting almost exclusively of bifacial lobes. Agaricia agaricites grows bifacial lobes as well, especially in the shallow zone where A. tenuifolia may be abundant, but its lobes are thicker and the rims are less wavy than in $A$. tenuifolia. In addition, $A$. agaricites tends to form more horizontal unifacial plates. At Willemstoren (Bonaire), both species co-exist and the morphological difference is obvious.

Another explanation is related to the organisms themselves; the host may be less attractive for gall crabs. To find only one crab among many host colonies at this and other (see below) localities suggests a less favourable environment for gall crabs. In Bonaire, coral colonies of other Agaricia Lamarck, 1801 species, such as $A$. agaricites and $A$. lamarcki, often host many gall crabs, a situation similar to that of Curaçao (van Tienderen and van der Meij, 2016). Ongoing adaptive divergence of $O$. hypostegus over Agariciidae corals, a possible sign of further diversification in this species, was suggested to cause the observed differences in host occurrence (van Tienderen and van der Meij, 2016; 2017).

Specific research on poorly investigated or rare species may result in new ecological data (Hoeksema et al., 2017). Especially in the presently threatened coral reef environments, ecological relationships should be studied before it is impossible to do so. Also, the gathered knowledge may have important applications for coral reef conservation. Off Bonaire, the presence of $A$. tenuifolia has decreased dramatically. For example at Playa Bengé $\left(12^{\circ} 17^{\prime} 27^{\prime \prime} \mathrm{N} 68^{\circ} 24^{\prime} 44^{\prime \prime} \mathrm{W}\right)$ in the Washington-Slagbaai National Park, only barren remnants remain of the grooves and spurs that carried an abundant cover of this coral in the late seventies and beginning of the eighties of the previous century (GvM pers. obs). Nevertheless, A. tenuifolia is still available for research at several locations along the eastern windward coast of Bonaire. Apart from Willemstoren, the species was also found at Mamparia
Gutu $\left(12^{\circ} 04^{\prime} 36^{\prime \prime} \mathrm{N} 68^{\circ} 13^{\prime} 49^{\prime \prime} \mathrm{W}\right)$ and in White Hole (12 $\left.05^{\prime} 39^{\prime \prime} \mathrm{N} 68^{\circ} 13^{\prime} 41^{\prime \prime} \mathrm{W}\right)$. During low-wind periods, waves and swell are reduced and offer appropriate research conditions to discover ecological relationships unknown from the better-studied leeward sides of Caribbean islands.

\section{ACKNOWLEDGEMENTS}

During underwater fieldwork at Bonaire GvM was accompanied by Micky Streefkerk. We thank two anonymous reviewers for their constructive comments.

\section{RefERENCES}

Aronson, R.; Bruckner, A.; Moore, J.; Precht, B. and Weil, E. 2008. Agaricia undata, Leptoseris cailleti. The IUCN Red List of Threatened Species 2008: e.T133100A3560174, e.T133686A3864752.

Fenner, D. 2001. Biogeography of three Caribbean corals (Scleractinia) and the invasion of Tubastraea coccinea into the Gulf of Mexico. Bulletin of Marine Science, 69: 1175-1189.

Hoeksema, B.W.; van Beusekom, M; ten Hove, H.A.; Ivanenko, V.N.; van der Meij, S.E.T. and van Moorsel, G.W.N.M. 2017. Helioseris cucullata as a host coral at St. Eustatius, Dutch Caribbean. Marine Biodiversity, 47: 71-78.

Kropp, R.K. and Manning, R.B. 1987. The Atlantic gall crabs, family Cryptochiridae (Crustacea: Decapoda: Brachyura). Smithsonian Contributions to Zoology, 462: 1-21.

Nelson, H. R.; Kuempel, C.D. and Altieri, A.H. 2016. The resilience of reef invertebrate biodiversity to coral mortality. Ecosphere, 7: e01399.

van der Meij, S.E.T. 2014. Host species, range extensions, and an observation of the mating system of Atlantic shallow-water gall crabs (Decapoda: Cryptochiridae). Bulletin of Marine Science, 90: 1001-1010.

van Duyl, F.C. 1985. Atlas of the living reefs of Curaçao and Bonaire (Netherlands Antilles). Utrecht, Natuurwetenschappelijke studiekring voor Suriname en de Nederlandse Antillen, 117, 35 p. Available at http:/ / www.dcbd.nl/document/atlas-livingreefs-curaçao-and-bonaire-netherlands-antilles

van Tienderen, K.M. and van der Meij, S.E.T. 2016. Occurrence patterns of coral-dwelling gall crabs (Cryptochiridae) over depth intervals in the Caribbean. Peer], 4: e1794.

van Tienderen, K.M. and van der Meij, S.E.T. 2017. Extreme mitochondrial variation in the Atlantic gall crab Opecarcinus hypostegus (Decapoda: Cryptochiridae) reveals adaptive genetic divergence over Agaricia coral hosts. Scientific Reports, 7: 39461.

Zlatarski, V.N. and Martínez-Estalella, N. 1982. Les Scléractiniaires de Cuba avec des données sur les organismes associés. Sofia, Editions l'Académie bulgare des Sciences, 472 p. 